\title{
KORELASI ANTARA MAKNA SITUS SEJARAH DENGAN SENSE OF PLACE
}

\author{
Atie Ernawati \\ Mahasiswa Program Doktoral Arsitektur, SAPPK, Institut Teknologi Bandung \\ Program Studi Arsitektur, Universitas Indraprasta PGRI \\ atie.ernawati@unindra.ac.id, atie2373@gmail.com
}

\begin{tabular}{ll}
\hline \multicolumn{2}{l}{ Informasi artikel } \\
\hline Sejarah & \\
artikel: & \\
Diterima & 26 Maret 2021 \\
Revisi & 29 Maret 2021 \\
Dipublikasikan & 30 Maret 2021 \\
\hline Kata kunci: &
\end{tabular}

Kata kunci:

Korelasi

Makna

Situs ziarah
Sense of place

\begin{abstract}
ABSTRAK
Upaya pelestarian Kawasan situs sejarah yang memiliki nilai historis yang cukup kuat banyak dilakukan melalui pendekatan fisik (tangible) maupun pendekatan non fisik (intangible) seperti restorasi, konservasi, preservasi dan lain-lain. Pada penelitian ini, peneliti berupaya melakukan kajian dengan pendekatan non fisik sebagai salah satu upaya pelestarian dengan melakukan analisis korelasi antara makna situs ziarah dengan sense of place. Dengan pendekatan kuantitatif, dilakukan proses analisis melalui dua tahap, tahap pertama adalah analisis konten/isi mulai dari penyebaran kuesioner, analisis open coding, axial coding hingga selektif coding. Tahap berikutnya analisis faktor dan analisis korelasi. Berdasarkan hasil analisis korelasi, didapat hasil bahwa makna religious memiliki hubungan yang kuat dengan rasa terikat pada kategori sense of place dengan nilai koefisien korelasi sebesar 0,64, sedangkan makna social budaya memiliki korelasi yang sedang dengan nilai koefisien korelasi sebesar 0,18. Sebaliknya, peziarah yang memiliki makna negative memiliki korelasi yang tinggi dengan rasa tidak terikat dengan nilai koefisien 0,52. Melalui penelitian ini diharapkan dapat dilakukan pendekatan berbasis perilaku sebagai salah satu upaya pelestarian Kawasan situs ziarah.

\section{ABSTRACT}

\section{Key word:}

Correlation

Meaning

Sense of place

Pilgrimage

\section{PENDAHULUAN}

Fenomena ziarah berkembang tidak hanya di negara-negara Timur Tengah maupun di benua India, di Indonesia pun fenomena ini sudah ada sejak lama, khususnya di pulau jawa. Tradisi ziarah telah ada sebelum masuknya ajaran Islam ke Indonesia. Masyarakat pemeluk agama hindu kerap melakukan ritual ziarah ke tempat-tempat suci seperti pura, candi dan lain-lain. Candi agung dipersepsikan sebagai tempat orang halus yang berbaik hati dan dapat dijadikan perantara untuk memohon berkah kepada yang maha kuasa (Wasita, 2018). Bagi masyarakat Jawa, makam merupakan tempat yang dianggap suci dan pantas dihormati. Makam sebagai tempat peristirahatan bagi arwah nenek moyang dan keluarga yang telah meninggal. Keberadaan makam dari tokoh tertentu menimbulkan daya tarik bagi masyarakat untuk melakukan aktivitas ziarah dengan berbagai motivasi. Situs-situs ziarah tersebut selain menjadi tempat sakral bagi mereka yang meyakininya, namun juga menjadi obyek pariwisata 
yang marak berkembang di masyarakat. Persepsi terhadap tempat yang dianggap suci ini mendorong motivasi untuk melakukan ritual dalam rangka mencari berkah. Motivasi para peziarah dibangun oleh adanya persepsi dan makna yang dirasakan tentang tempat-tempat ziarah yang mereka kunjungi (Wasita, 2018). Makna yang terbentuk inilah yang telah membangun sense of place pada masingmasing individu peziarah maupun masyarakat sekitarnya.

Tradisi ziarah secara turun temurun telah dilestarikan oleh masyarakat dan para komunitas peziarah dengan berbagai motivasi dan tujuan. Hal ini tidak terlepas dari konsepsi masyarakat dan pandangan mereka terhadap aktivitas ziarah. Menurut Koenjaraningrat (1984:185), orang yang meninggal, arwahnya tetap memiliki daya sakti, yaitu dapat memberikan pertolongan kepada orang yang masih hidup sehingga anak cucu yang masih hidup senantiasa berusaha untuk tetap berhubungan dan memujanya. Hal ini disebabkan karena dalam pandangan masyarakat Jawa bahwa roh yang meninggal itu bersifat abadi. Untuk itu, aktivitas berziarah dianggap sebagai bentuk manifestasi seseorang atau kelompok terhadap sebuah keyakinan. Menurut Abdullah, dkk (2008:3) keyakinan-keyakinan keagamaan tiada lain merupakan refleksi dari masyarakat itu sendiri, dengan ritual keagamaan yang diperkuat melalui solidaritas kelompok dan kepercayaan pada tatanan moral.

\section{Makna Situs Sejarah}

Dalam agama Islam sendiri sebenarnya kegiatan ziarah marak dilakukan pada saat melaksanakan rukun Islam yang kelima Haji ataupun Umroh ke tanah suci Mekah dan Madinah, dimana terdapat makam Rasulullah dan para nabi serta para sahabat Rasululloh SAW. Dalam rangkaian aktivitas ibadah haji, mereka dianjurkan untuk mengunjungi makam Rasululluh di dalam linglungan masjid Nabawi di Kota Madinah dan para sahabat guna mengenang dan mengambil ibrah dari perjuangan Mereka. Ziarah juga sebenarnya dianjurkan seperti yang tercantum dalam hadist Rasullullah yang berbunyi: "berziarah kuburlah, sesungguhnya hal itu akan mengingatkan kalian terhadap akhira."(HR.Muslim)

Tujuan dari ziarah tersebut selain untuk mendoakan ahli kubur agar dilapangkan kuburnya dan diampuni segala dosa-dosanya dari siksa kubur, melembutkan hati dan memadamkan kesombongan, meneteskan air mata, serta agar manusia banyak mengingat kematian dan bahwa ada kehidupan lain sesudah mati sehingga dalam tidak lanjutnya tidak ujub dunia. Namun pada aktivitasnya, para peziarah ini memiliki motivasi yang beragam. Dalam berziarah, setiap muslim berkewajiban berpegang dengan syaraiat dan waspada terhadap bid'ah dalam berziarah kubur. Ziarah kubur yang disyariahkan bagi kubur kaum muslimin semuanya itu sama, baik kubur itu milik wali atau bukan. Karena setiap mukmin baik laki-laki maupun perempuan, semuanya adalah wali Allah. Namun secara umum, para peziarah yang berkunjung ke situs-situs peziarahan didorong oleh motivasi agama dan dorongan keyakinan untuk menghormati tokoh yang akan dikunjungi.

Kehadiran para peziarah tidak hanya mendapatkan sorotan positif sebagai obyek wisata, namun juga pandangan negatif dari sebagian masyarakat yang menganggap aktifitas ini sebagai kegiatan yang menyimpang bahkan dianggap syirik oleh sebagian ahli agama. Terlepas dari persoalan yang menyimpang, keberadaan situs ziarah ini telah menjadi saksi bagi sejarah perjuangan bangsa, dan figur para tokoh dalam situs ziarah tersebut yang memiliki peran yang sangat besar dalam memperjuangkan kemerdekaan Indonesia dengan agama dan ilmu yang mereka miliki, dan karomah serta kesaktian yang mereka miliki masih dipercaya sebagian masyarakat sehingga mereka dengan keimanan dan keyakinan yang dimiliki datang untuk sekedar berziarah mendoakan para ahli kubur tersebut ataupun sekedar mengharapkan karomah dari sang tokoh yang diyakini tetap ada meski mereka telah tiada. Aktivitas para peziarah yang datang dengan berbagai macam tujuan dan motivasi, 
seringkali memperlihatkan sikap spiritual yang kuat, hal ini didorong oleh konsepsi peziarah terhadap keberadaan situs.

\section{Pendekatan Sense of Place dalam Upaya Pelestarian Situs Ziarah}

Gagasan terkini tentang pelestarian lingkungan perkotaan tidak lagi sekedar pada upaya mempertahankan keaslian sejarah kota, namun juga membahas penciptaan pengalaman urban yang khas serta tetap memiliki identitas kesejarahan. Upaya mewujudkan sense of place dinilai lebih penting ketimbang hanya melakukan restorasi elemen fisik urban (Martokusumo, 2014). Ditegaskan lagi oleh Martokusumo, salah satu focus dari kegiatan pelestarian lingkungan perkotaan adalah penerapan sense of place pada Kawasan urban tertentu. Sense of place juga berhubungan dengan upaya peningkatan kualitas.

Pendekatan konsep sense of place dapat digunakan untuk menjelaskan fungsi-fungsi persepsi manusia dan lingkungannya, termasuk perilaku masyarakat. konsep sense of place mencirikan hubungan kompleks manusia/masyarakat dengan lingkungan yang mereka hadapi. Sense of place banyak diterima sebagai sebuah konsep untuk menelusuri isu-isu seperti preferensi, akses control sumber daya alam, makna dan budaya serta partisipasi masyarakat lokal.

Menurut Montgomery (2003), Upaya konservasi Kawasan menerapkan konsep sense of place diperoleh diperoleh dari jalinan setting fisik (form), kegiatan yang terjadi, dan citra (image).

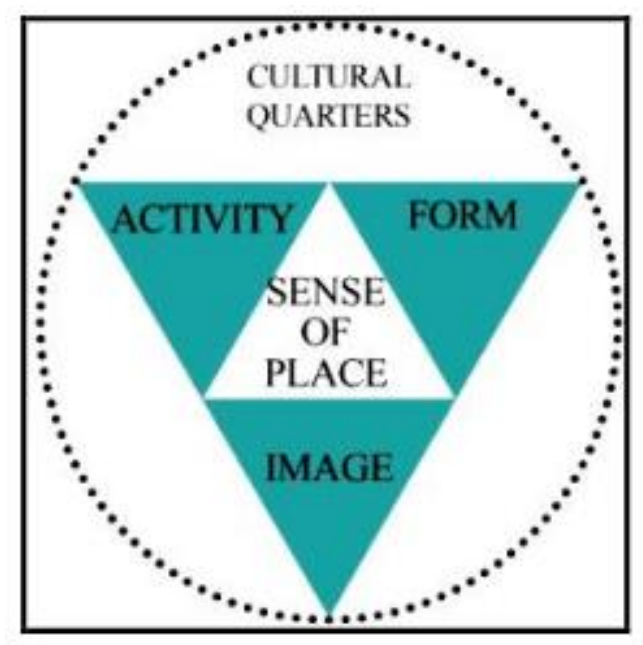

Gambar 1. Diagram Sense of Place

Oleh John Montgomery

Sumber: Carmona, 2003

Menurut Nielsen-Pincus, Hall, Force dan Wulfhorst (2010), sense of place melibatkan interaksi pengaruh dan emosi, pengetahuan dan kepercayaan, dan perilaku dan tindakan yang mengacu pada tempat. Sense of place adalah seperangkat ikatan antara individu dan tempat yang mencakup komponen afektif, kognitif dan perilaku, yang dianggap sebagai payung dari tiga konstruksi: (1) Place attachment, yang didefinisikan sebagai "ikatan positif yang berkembang antara suatu orang dan lingkungannya ", (2) Identitas tempat, yang merupakan" identitas seseorang yang berkaitan dengan lingkungan fisik ", dan (3) Ketergantungan tempat, yang dianggap sebagai" kekuatan yang dirasakan dari hubungan antara seseorang dan seorang tempat "(Jorgensen dan Stedman, 2001). Williams, Patterson, Roggenbuck dan Watson (1992) menyatakan bahwa sense of place sering dikaitkan dengan ikatan emosional atau afektif antara individu dan tempat tertentu, yang sangat mirip dengan definisi attachment place oleh Jorgensen en Stedman (2001). Willams et al. (1992) menggambarkan bahwa 
Place attachment terdiri dari dua konseptualisasi utama, place dependence dan place identity. Selain itu, Shamsuddin dan Ujang (2008) menggunakan place attachment sebagai elemen sense of place dan mendefinisikan place attachment sebagai ikatan yang dibangun antara individu dan tempat. Place attachment tercermin dalam identitas pengguna dan ketergantungan pada pengaturan mereka. Shamsuddin dan Ujang (2008) menemukan dalam penelitian mereka bahwa place attachment sangat dibentuk oleh atribut sosial-budaya yang fungsional, emosional, menghasilkan keterikatan emosional dan fungsional pada tempat. Jorgensen dan Stedman (2001) mengukur sense of place melalui 12 item dari place attachment, place identity dan place dependence.

Tabel 1. Question Relaxing to Sense of Place

\begin{tabular}{|l|l|}
\hline Factor & Item description \\
\hline \multirow{4}{*}{ Place attachment } & I feel relaxed when I am at my lake property \\
\cline { 2 - 3 } & I feel happiest when I am at my lake property \\
\hline & My lake property is my favorite place to be \\
\hline \multirow{5}{*}{ Place identity } & I really miss my lake property when I am away from it for too long \\
\hline & Everything about my lake property is a reflection of me \\
\hline & My lake property says very little about who I am \\
\hline & I feel that I can really be myself at my lake property \\
\hline My lake property reflects the type of person I am \\
\hline \multirow{5}{*}{ Place dependence } & My lake property is the best place for doing the things that I enjoy most \\
\hline & For doing the things I enjoy most, no other place can compare to my lake property \\
\hline & My lake property is not a good place to do the things I most like to do \\
\hline & As far as I am concerned, there are better places to be than at my lake property \\
\hline
\end{tabular}

Sumber: J.J. Boerebach (2012)

Berdasarkan sumber tersebut, pada penelitian ini digunakan beberapa pertanyaan untuk mengetahui tingkatan sense of place pada situs ziarah.

\section{METODOLOGI}

Penelitian ini menggunakan pendekatan kuantitatif dengan tujuan mengetahui hubungan atau korelasi antara makna situs ziarah dengan sense of place. Data diperoleh melalui penyebaran kuesioner kepada 120 responden secara random. Data dianalisis secara tekstual.

\section{Metode Pengumpulan Data}

Data dikumpulkan dengan menggunakan survei berbentuk kuesioner online, dengan pertanyaan terbuka (open-ended) yang berupa teks, dibagikan secara bebas (snowball-non-randomsampling) lewat media social mulai dari keluarga, teman, ataupun rekan sejawat. Pertanyaan dijawab dalam bentuk teks, dimana responden menulis konsepsinya tentang makna yang dirasakan pada situs ziarah. Jumlah responden yang terkumpul adalah 121 orang.

\section{Karakteristik Responden}

Pada penelitian ini, jumlah responden terdiri dari 121 responden dimana 45,5\% adalah perempuan dan 54,5\% Penyebaran kuesioner dilakukan secara acak (random sampling) kepada 121 responden. Secara umum data memperlihatkan bahwa yg banyak melakukan ziarah adalah usia 22-25 tahun, dan usia di atas 40 tahun adalah laki-laki. 


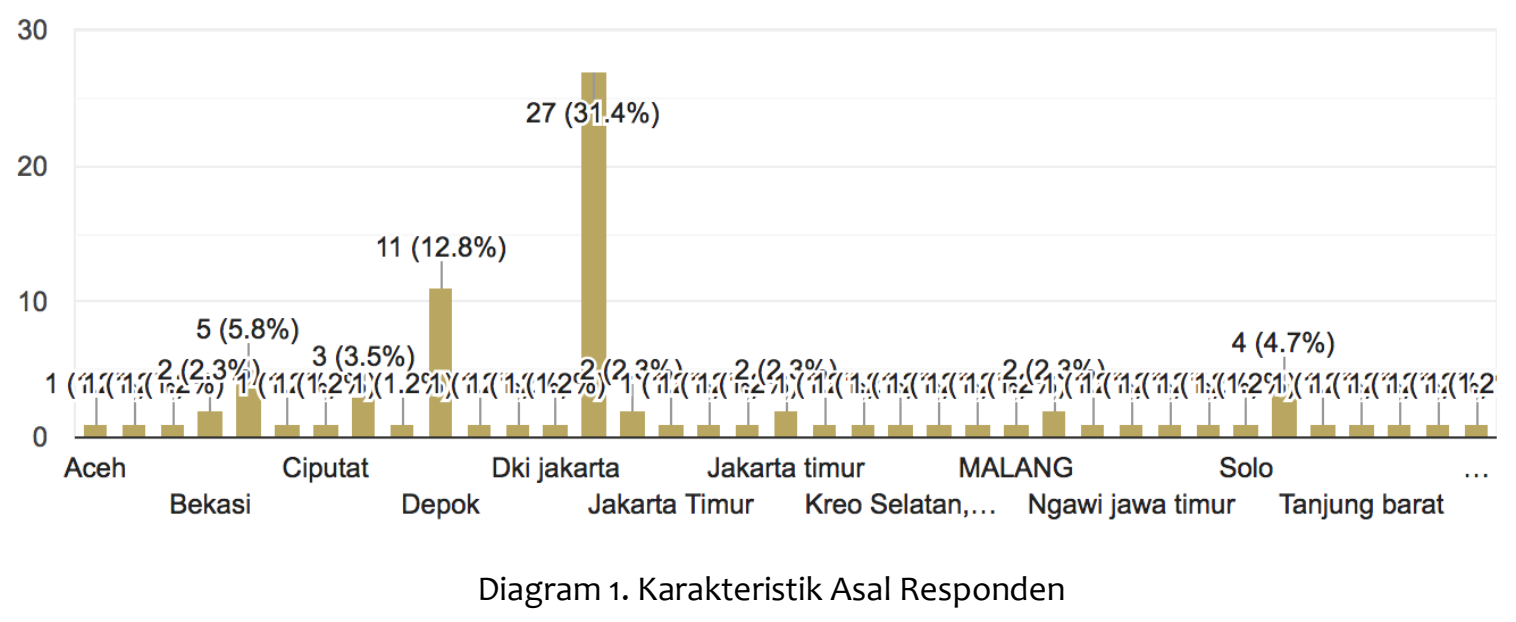

Berdasarkan asal tempat tinggal diperoleh data sebesar 31,4\% berasal dari Jakarta, 12,8\% berasal dari Bekasi, selebihnya dari luar jabodetabek.

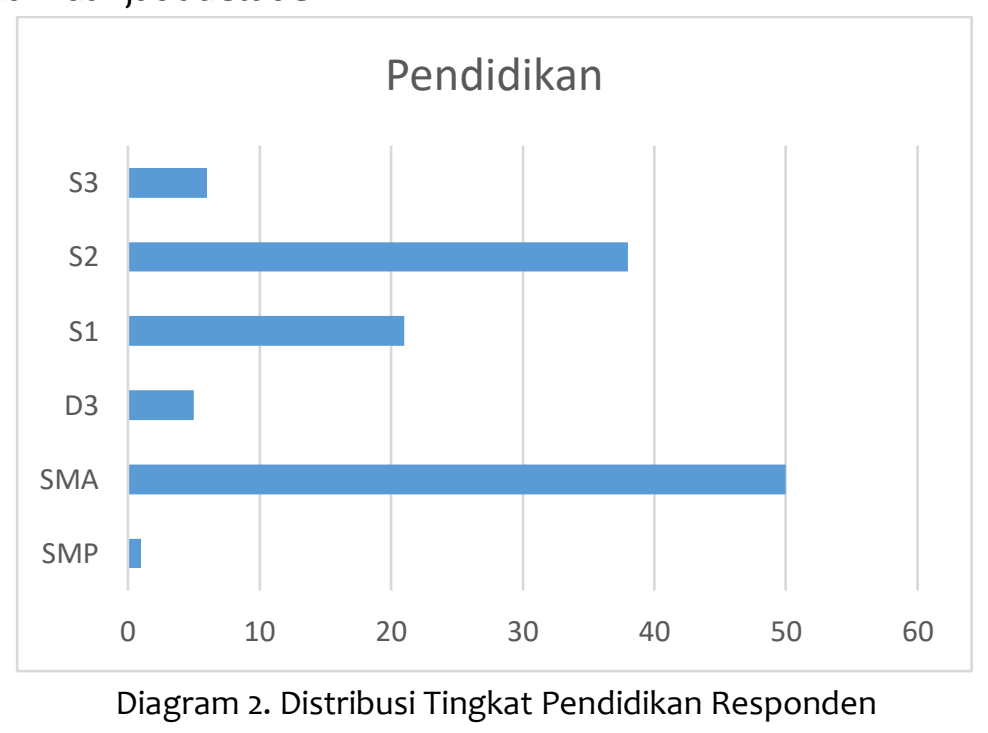

Sebagian besar responden memiliki Pendidikan S2 dengan jumlah 38 orang, S3 6, S1 21, D3 5, SMA 50 dan SMP 1 orang.

Berdasarkan hasil penyebaran kuesioner tersebut, data dianalisis melalui 2 tahap yakni analisis konten dan analisis Isi.

\section{HASIL DAN PEMBAHASAN}

\section{Analisis dan Interpretasi}

\section{Analisis Konten (content Analysis)}

Pada penelitian analisis konten/analisis isi dilaksanakan melalui beberapa tahap, yakni :

1. Penyebaran kuesioner

2. Open coding

3. Axial coding

4. Selective coding

Tahapan analisis awal yang dilakukan oleh peneliti berupa analisis konten (content analysis) diperoleh beberapa kata kunci (berupa data teks) dari beberapa pertanyaan yang diberikan secara terbuka 
(open coding) tentang konsepsi responden terhadap makna ziarah. Berikut contoh komentar responden (open coding) sehingga dapat dikelompokkan menjadi kata kunci dan kategori pada tahap axial coding:

Tabel 2. Axial Coding tentang Makna Ziarah

\begin{tabular}{|c|c|c|c|}
\hline Komentar tentang Makna Situs Ziarah & Kata Kunci & Sub Kategori & Kategori \\
\hline \multirow{6}{*}{$\begin{array}{l}\text { memberikan ketenangan dan } \\
\text { kedekatan dengan sang pencipta karena } \\
\text { situs ziarah tersebut merupakan tempat } \\
\text { yang penuh barokah karena ada banyak } \\
\text { masyarakat yang datang untuk beribadah } \\
\text { (sholat, zikir, mengaji, dII) dan 7oesame7oa } \\
\text { took wali Allah yang dmakamkan di tempat } \\
\text { tersebut memberikan barokah dan } \\
\text { mashlahat kepada masyarakat meski telah } \\
\text { tiada }\end{array}$} & Ketenangan & Memberikan ketenangan & Makna religi \\
\hline & $\begin{array}{l}\text { Kedekatan dengan sang } \\
\text { pencipta }\end{array}$ & $\begin{array}{l}\text { Tempat yang } \\
\text { mendekatkan diri dengan } \\
\text { Allah }\end{array}$ & Makna religi \\
\hline & $\begin{array}{l}\text { Tempat yang penuh } \\
\text { barokah }\end{array}$ & Tempat penuh barokah & Makna religi \\
\hline & $\begin{array}{l}\text { Banyak masyarakat } \\
\text { beribadah }\end{array}$ & Tempat ibadah & Makna religi \\
\hline & Sesama wali Allah & kharismatik & ketauladanan \\
\hline & $\begin{array}{l}\text { Memberikan } \\
\text { kemaslahatan }\end{array}$ & Memberikan mashlahat & Makna religi \\
\hline \multirow[t]{2}{*}{$\begin{array}{l}\text { Untuk mengingat kematian dan } \\
\text { melestarikan salah satu kebudayaan pada } \\
\text { makam tsb. }\end{array}$} & Mengingat kematian & $\begin{array}{l}\text { Tempat yang } \\
\text { mengingatkan kematian }\end{array}$ & Makna Religi \\
\hline & Melestarikan kebudayaan & $\begin{array}{l}\text { Tempat yng memiliki nilai } \\
\text { budaya }\end{array}$ & Makna budaya \\
\hline
\end{tabular}

Tabel 3. Kerangka Pikir Makna Situs Ziarah

\begin{tabular}{|c|c|c|c|}
\hline Variabel Utama & Kategori & Subkategori & Variabel Operasional \\
\hline \multirow[t]{16}{*}{ Makna Ziarah } & Ketauladanan & Karismatik & $\begin{array}{l}\text { Bentuk ketauladanan karena kekaguman terhadap para wali Allah } \\
\text { karena keistiqomahannya dan perjuangannya }\end{array}$ \\
\hline & $\begin{array}{l}\text { Makna } \\
\text { Budaya }\end{array}$ & Nilai Budaya & Sebagai tempat yang memiliki warisan budaya yang kuat \\
\hline & \multirow{2}{*}{$\begin{array}{l}\text { Makna } \\
\text { sejarah dan } \\
\text { edukasi }\end{array}$} & $\begin{array}{l}\text { Tempat yang memilki nilai } \\
\text { sejarah }\end{array}$ & sebagai tempat yang memiliki nilai sejarah yang tinggi \\
\hline & & $\begin{array}{l}\text { Tempat yang memiliki nilai } \\
\text { edukasi }\end{array}$ & sebagai tempat yang memiliki nilai edukasi \\
\hline & \multirow[t]{9}{*}{ Makna religi } & Makna sakral/suci & situs ziarah merupakan tempat yang sakral dan suci \\
\hline & & Tempat wisata religi & situs ziarah merupakan tempat wisata religi \\
\hline & & $\begin{array}{lr}\text { Tempat } & \text { untuk } \\
\text { mendekatkan diri kepada } \\
\text { Allah }\end{array}$ & suasana situs mendorong kita untuk mendekatkan diri kepada Allah \\
\hline & & Tempat penuh barokah & situs ziarah merupakan tempat yang penuh barokah \\
\hline & & Tempat religius & tempat untuk beribadah \\
\hline & & $\begin{array}{ll}\text { Tempat } & \text { yang } \\
\text { mengingatkan } & \text { pada } \\
\text { kematian } & \\
\end{array}$ & $\begin{array}{l}\text { situs ziarah merupakan tempat yang dapat mengingatkan kita pada } \\
\text { kematian dan akhirat }\end{array}$ \\
\hline & & $\begin{array}{l}\text { Tempat yang memberikan } \\
\text { ketenangan }\end{array}$ & suasana situs ziarah mampu memberikan ketenangan \\
\hline & & $\begin{array}{l}\text { Tempat yang dapat } \\
\text { meningkatkan keimanan }\end{array}$ & suasana situs dapat meningkatkan keimanan \\
\hline & & Tempat untuk refleksi diri & suasana situs mendorong saya untuk melakukan refleksi diri \\
\hline & Makna sosial & Tempat bersilaturahmi & $\begin{array}{l}\text { situs ziarah sebagai tempat bertemu dan bersilaturahim dengan } \\
\text { 70esame komunitas }\end{array}$ \\
\hline & \multirow{2}{*}{$\begin{array}{l}\text { Tidak } \\
\text { bermakna }\end{array}$} & Tidak bermakna & situs ziarah hanya sebuah makam, tidak bermakna \\
\hline & & Tempat syirik & situs ziarah tempat yang sarat akan kesyirikan dan bid'ah \\
\hline
\end{tabular}

Analisis data teks dilakukan untuk mencari kesamaan persepsi tentang makna situs ziarah, mengelompokkannya menjadi kata kunci untuk mencari kesamaan dan kemiripan sehingga dapat dikelompokkan menjadi kategori. Berdasarkan hasil pengumpulan data, makna situs ziarah dapat dikelompokkan menjadi 9 kategori yakni ketauladanan, makna budaya, makna sejarah dan edukasi, makna religi, makna social dan tidak bermakna. 
Tabel 4. Kerangka tentang Sense of Place berdasarkan Teori Jorgensen dan Stedman (2001) dalam JJ Boerebach (2012)

\begin{tabular}{|c|c|c|c|}
\hline $\begin{array}{l}\text { Variabel } \\
\text { Utama }\end{array}$ & Kategori & Sub Kategori & Variabel Operasional \\
\hline \multirow[t]{12}{*}{$\begin{array}{l}\text { Sense of } \\
\text { Place }\end{array}$} & \multirow[t]{4}{*}{ Place Attachment } & $\begin{array}{l}\text { Saya merasa relax ketika saya berada di situs } \\
\text { ziarah }\end{array}$ & Situs ziarah membuat saya merasa relax \\
\hline & & $\begin{array}{l}\text { Saya merasa bahagia ketika saya berada di } \\
\text { situs ziarah }\end{array}$ & Situs ziarah membuat saya merasa bahagia \\
\hline & & Situs ziarah merupakan tempat favorit saya & $\begin{array}{l}\text { Situs ziarah merupakan satu-satunya tempat } \\
\text { favorit saya }\end{array}$ \\
\hline & & $\begin{array}{l}\text { Saya akan rindu ketika saya jauh dari situs } \\
\text { ziarah }\end{array}$ & $\begin{array}{l}\text { Saya tidak akan merindukan tempat ini jika } \\
\text { tidak ada situd ziarah }\end{array}$ \\
\hline & \multirow[t]{4}{*}{ Place identity } & $\begin{array}{l}\text { Segala sesuatu tentang situs ziarah merupakan } \\
\text { refleksi dari diri saya }\end{array}$ & $\begin{array}{l}\text { Situs ziarah mencerminkan tipe seperti apa } \\
\text { saya }\end{array}$ \\
\hline & & $\begin{array}{l}\text { Situs ziarah mengatakan sangat sedikit siapa } \\
\text { saya }\end{array}$ & $\begin{array}{l}\text { Tempat ini mengatakan sangat sedikit } \\
\text { tentang saya (negative) }\end{array}$ \\
\hline & & $\begin{array}{l}\text { Saya merasa bahwa saya benar-benar bisa } \\
\text { menjadi diri saya sendiri di tempat ini }\end{array}$ & $\begin{array}{l}\text { Saya merasa bahwa saya benar-benar } \\
\text { menjadi diri sendiri di tempat ini }\end{array}$ \\
\hline & & $\begin{array}{l}\text { Situs ziarah memperlihatkan type saya seperti } \\
\text { apa }\end{array}$ & Situs ziarah adalah cerminan saya \\
\hline & \multirow[t]{4}{*}{$\begin{array}{l}\text { Place } \\
\text { dependence }\end{array}$} & $\begin{array}{l}\text { Situs ziarah adalah tempat terbaik untuk saya } \\
\text { melakukan sesuatu sehingga saya enjoy disana }\end{array}$ & $\begin{array}{l}\text { Tempat ini memenuhi kebutuhan saya lebih } \\
\text { baik daripada tempat lain }\end{array}$ \\
\hline & & $\begin{array}{l}\text { Untuk melakukan sesuatu, saya sangat } \\
\text { menikmati, tidak ada tempat yang lain yang } \\
\text { bisa dibandingkan dengan situs itu }\end{array}$ & $\begin{array}{l}\text { Tempat ini adalah tempat terbaik untuk } \\
\text { melakukan sesuatu sehingga saya paling } \\
\text { menikmati }\end{array}$ \\
\hline & & $\begin{array}{l}\text { Ini bukan tempat yang baik untuk melakukan } \\
\text { hal-hal yang paling saya sukai }\end{array}$ & $\begin{array}{l}\text { Tempat ini adalah tempat yang baik untuk } \\
\text { melakukan hal-hal yang paling saya sukai }\end{array}$ \\
\hline & & $\begin{array}{l}\text { Sejauh yang saya ketahui, ada tempat yang } \\
\text { lebih baik daripada tempat ini }\end{array}$ & $\begin{array}{l}\text { Sejauh yang saya ketahui, ada tempat yang } \\
\text { lebih naik (negative) }\end{array}$ \\
\hline
\end{tabular}

Tahap terakhir dari analisis konten adalah selectif coding untuk mengetahui hubungan atau pengaruh dari beberapa dengan melakukan analisis korespodensi. Untuk itu akan dilihat beberapa hubungan dari beberapa factor dengan menggunakan warb hierechical clustering yang dapat dilihat melalui diagram dendogram.

\section{Analisis Korelasi}

Korelasi merupakan salah satu Teknik analisis statistic yang digunakan untuk mencari hubungan antara dua variable yang bersifat kuantitatif. Hubungan dua variable tersebut dapat terjadi karena adanya hubungan sebab akibat atau dapat pula terjadi karena kebetulan saja. Dua variable dikatakan berkorelasi apabila perubahan pada variable yang satu akan diikuti perubahan pada variable yang lain secara teratur dengan arah yang sama (korelasi positif) atau berlawanan (korelasi negative). Dalam kaitannya dengan tahapan sebelumnya (analisis Isi), analisis korelasi dalam penelitian ini dilaksanakan melalui beberapa langkah:

1. Membuat kerangka kuesioner

2. Penyebaran Kuesioner

3. Factor Analyze (FA)

4. Correlation Analysis (CA)

\section{Penentuan Komponen Prinsip/Faktor Analisis}

Penelitian ini melakukan 2 (dua) analisis factor, yakni berkaitan dengan makna situs ziarah dan sense of place. Pada analisis factor makna ziarah terdiri dari 6 kategori. Berdasarkan grafik eigenvalue terdapat 3 faktor yang nilainnya di atas 1 dari 12 faktor, untuk itu dari 3 faktor tersebut dianalisis menjadi 3 kategori yakni makna religious, makna social budaya dan makna negative. 


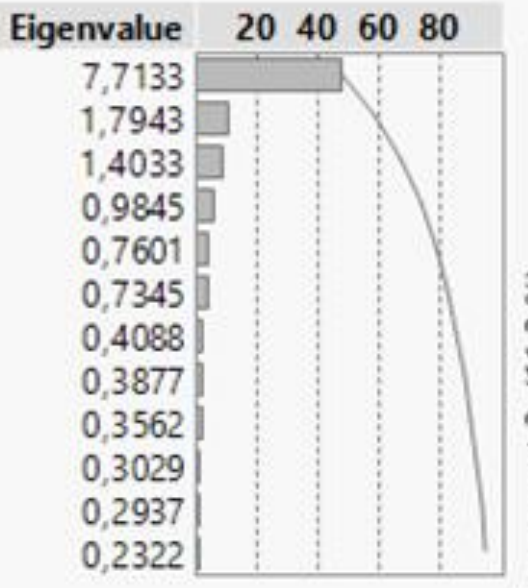

Diagram 3. Nilai Eigenvalue

Tabel 5. Analisis Faktor Makna Ziarah

\begin{tabular}{|c|c|c|c|}
\hline Variabel Operasional & Makna Religius & $\begin{array}{l}\text { makna sosial } \\
\text { budaya }\end{array}$ & makna negaif \\
\hline Situs ziarah merupakan tempat yang penuh barokah & 0,82 & 0,30 & $-0,06$ \\
\hline Suasana situs ziarah mampu memberikan ketenangan & 0,77 & 0,36 & 0,04 \\
\hline Situs ziarah merupakan tempat untuk beribadah & 0,77 & 0,17 & 0,18 \\
\hline Suasana situs ziarah mengingatkan saya pada kematian dan akhirat & 0,70 & 0,09 & $-0,07$ \\
\hline $\begin{array}{l}\text { Situs ziarah merupakan tempat bertemu dan bersilaturahim dengan } \\
\text { 72esame komunitas }\end{array}$ & 0,65 & 0,35 & 0,18 \\
\hline Situs ziarah sebagai tempat yang memiliki nilai sejarah yang tinggi & 0,25 & 0,83 & 0,02 \\
\hline Situs ziarah sebagai tempat yang memiliki warisan budaya yang kuat & 0,30 & 0,82 & $-0,03$ \\
\hline Situs ziarah merupakan tempat wisata religi & 0,36 & 0,68 & 0,03 \\
\hline Situs ziarah tempat yang sarat akan kesyirikan dan bid'ah & $-0,07$ & 0,04 & 0,89 \\
\hline Situs ziarah hanya sebuah makam, tidak bermakna & 0,07 & $-0,02$ & 0,90 \\
\hline
\end{tabular}
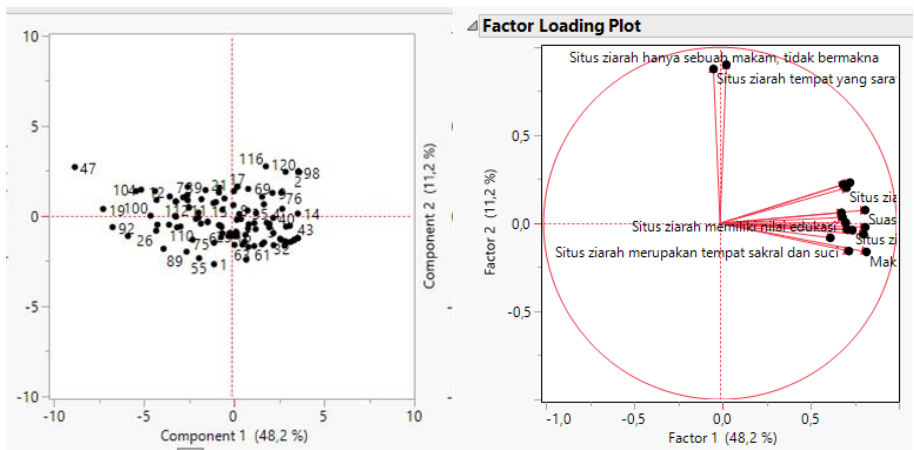

Diagram 4. Korelasi Priciple Component pada Sub-kategori Makna Situs Ziarah 
Pada analisis factor kedua (Sense of Place) terdapat 3 kategori yang terdiri dari 12 faktor. Jumlah komponen prinsip yang digunakan adalah dengan melihat nilai cumulative percent di bawah $95 \%$ sehingga didapat 2 komponent dari sense of place yakni rasa terikat dan tidak terikat.

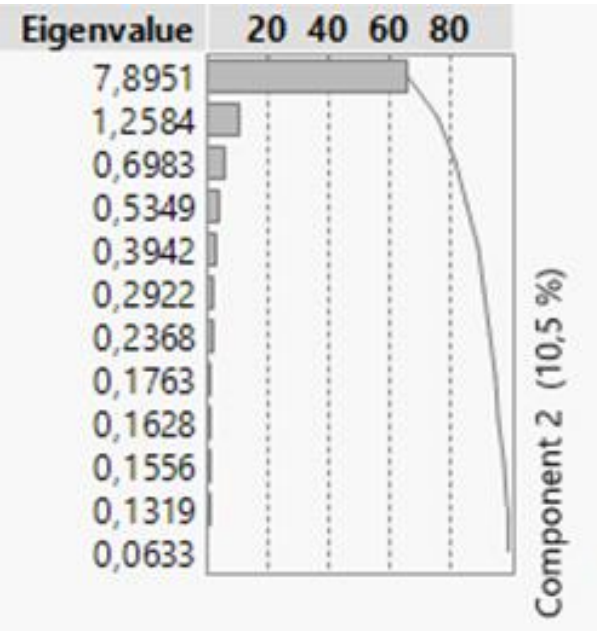

Diagram 5. Nilai Eigenvalue Sense of Place

Tabel 6. Hasil Analisis Faktor Sense of Place

\begin{tabular}{|c|c|c|}
\hline \multirow{2}{*}{$\begin{array}{l}\text { Variabel Operasional } \\
\text { Situs ziarah ini memenuhi kebutuhan saya lebih baik dari tempat lain }\end{array}$} & \multicolumn{2}{|c|}{ terikat terikat } \\
\hline & 0,89 & 0,13 \\
\hline Tempat ini adalah tempat terbaik untuk melakukan sesuatu sehingga saya paling menikmati & 0,89 & 0,22 \\
\hline Situs ziarah adalah cerminan saya & 0,88 & 0,22 \\
\hline Situs ziarah merupakan satu-satunya tempat favorit saya & 0,88 & 0,12 \\
\hline Saya merasa bahwa saya benar-benar menjadi diri sendiri di tempat ini & 0,86 & 0,25 \\
\hline Situs ziarah mencerminkan type seperti apa saya & 0,85 & 0,24 \\
\hline Situs ziarah membuat Saya merasa relax & 0,82 & 0,18 \\
\hline Tempat ini adalah tempat yang baik untuk melakukan hal-hal yang paling saya sukai & 0,80 & 0,33 \\
\hline Situs ziarah membuat Saya merasa bahagia & 0,78 & 0,10 \\
\hline Saya tidak akan merindukan tempat ini jika tidak ada situs ziarah nya & 0,77 & 0,20 \\
\hline Tempat ini mengatakan sangat sedikit tentang saya (negatif) & 0,32 & 0,82 \\
\hline sejauh yang Saya ketahui, ada tempat lain yang lebih baik (negatif) & 0,08 & 0,91 \\
\hline
\end{tabular}
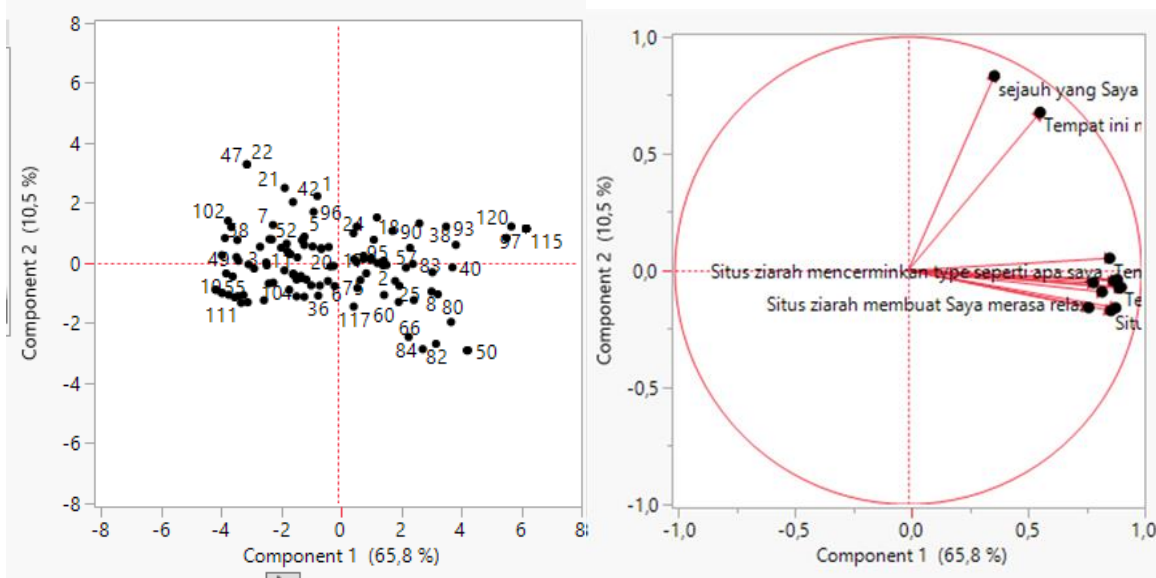

Diagram 6. Korelasi Principal Component pada Sub-kategori Sense of Place 


\section{Correlation Analysis (CA)}

Kedua factor yang telah dilakukan sebelumnya dianalisis kembali menggunakan metode analisis korelasi multivariate untuk mengetahui hubungan antara makna situs ziarah dengan sense of place.hasil dari analisis korelasi multivariate menunjukkan hubungan antara kelompok factor makna ziarah dan kelompok factor sense of place.

Tabel 7. Analisis Faktor

\begin{tabular}{lccccr}
\hline & makna religius & $\begin{array}{c}\text { makna sosial } \\
\text { budaya }\end{array}$ & makna negatif & terikat tidak terikat \\
\hline makna religius & & & & & \\
makna sosial budaya & 1,00 & 0,00 & 0,00 & 0,64 & 0,01 \\
\hline makna negatif & 0,00 & 1,00 & 0,00 & 0,18 & 0,02 \\
\hline terikat & 0,00 & 0,00 & 1,00 & 0,16 & 0,52 \\
\hline tidak terikat & 0,64 & 0,18 & 0,16 & 1,00 & 0,00 \\
\hline & 0,01 & 0,02 & 0,52 & 0,00 & 1,00 \\
\hline
\end{tabular}

Tabel 8. Analisis Korelasi antara Makna Ziarah dan Sense of Place

\begin{tabular}{|l|r|r|}
\hline \multicolumn{1}{|c|}{$\mathrm{X}$} & \multicolumn{2}{|c|}{ tidak } \\
\hline makna religius & terikat & \multicolumn{2}{|c|}{ terikat } \\
\hline makna sosial budaya & 0,64 & 0,01 \\
\hline makna negatif & 0,18 & 0,02 \\
\hline
\end{tabular}

Berdasarkan hasil analisis korelasi bivariate di atas memperlihatkan bahwa makna religious memiliki korelasi yang tinggi dengan rasa terikat dengan nilai koefisienmkorelasi sebesar 0,68, sedangkan makna social budaya memiliki korelasi yang sedang dengan nilai koefisien korelasi sebesar 0,18. Sebaliknya, makna negative memilki krelasi yang rendah dengan rasa terikat dibandindingkan dengan tidak terikat dengan nilai koefisien korelasi sebesar 0,52. Pada matiks scatterplot menunjukkan bahwa setiap sebaran menunjukkan hubungan antara sepasang variable. Dari hasil tersebut,nilai-nilai korelasi multivariat antar variable kemudian diolah dalam analisis korelasi .

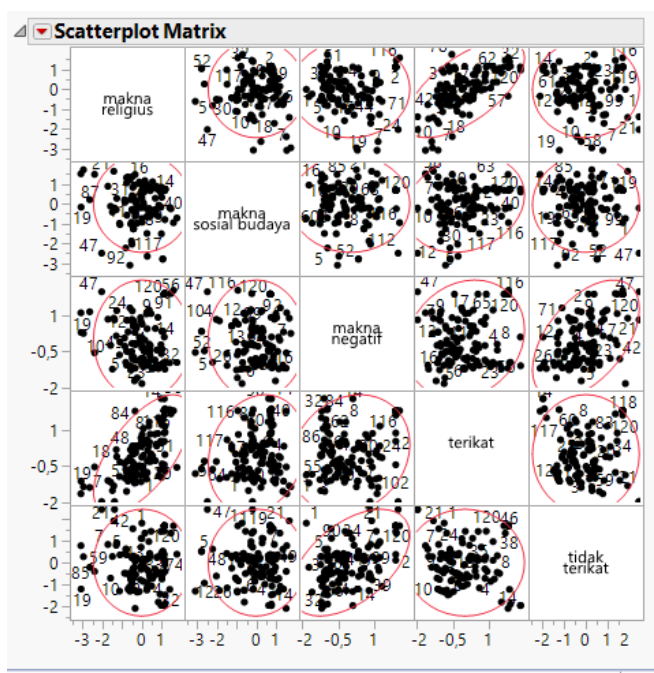

Diagram 7. Scatterplot Matrix antara Makna Ziarah dan Sense of Place 


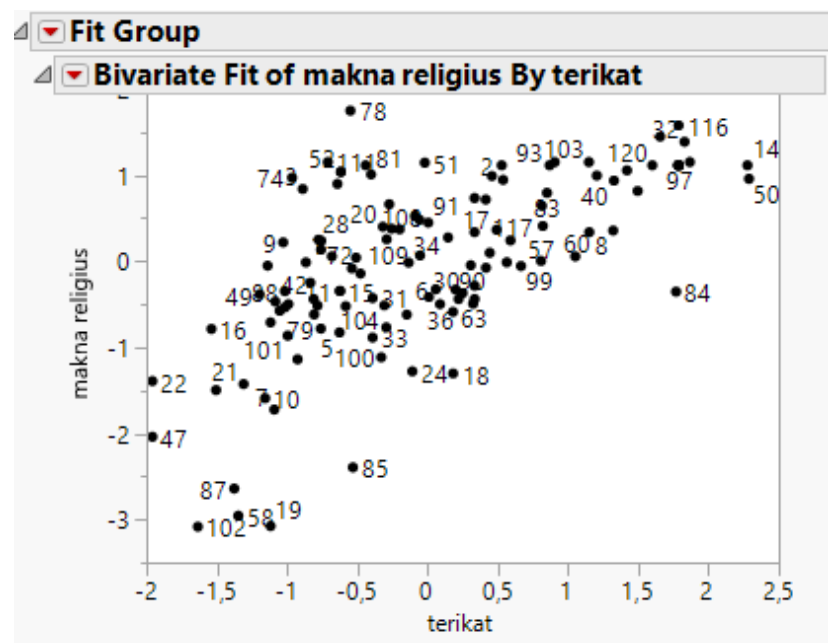

Diagram 8. Tingkat Kepadatan antara Makna Religious dengan Sense of Place

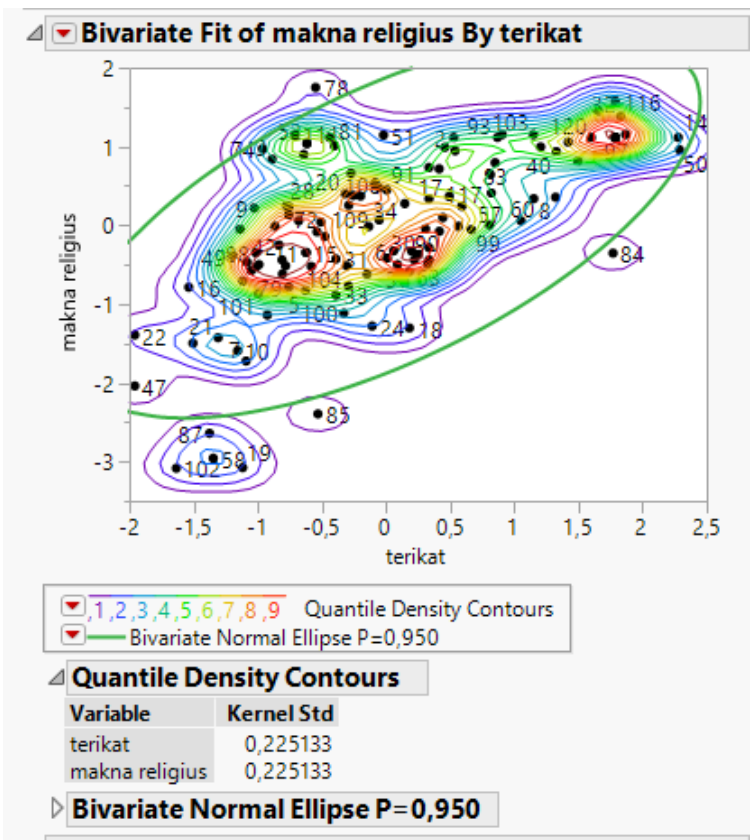

Diagram 9. Density Contour antara Makna Religious dan Rasa 'terikat'

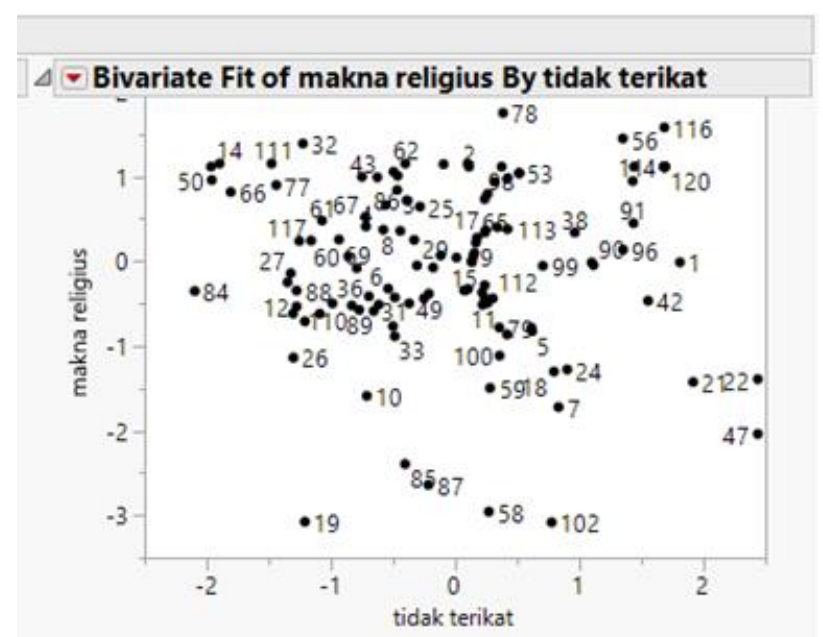

Diagram 10. Tingkat Kepadatan antara Makna Sosial Budaya dengan Sense of Place 
76 Korelasi antara Makna Situs Sejarah dengan Sense of Place

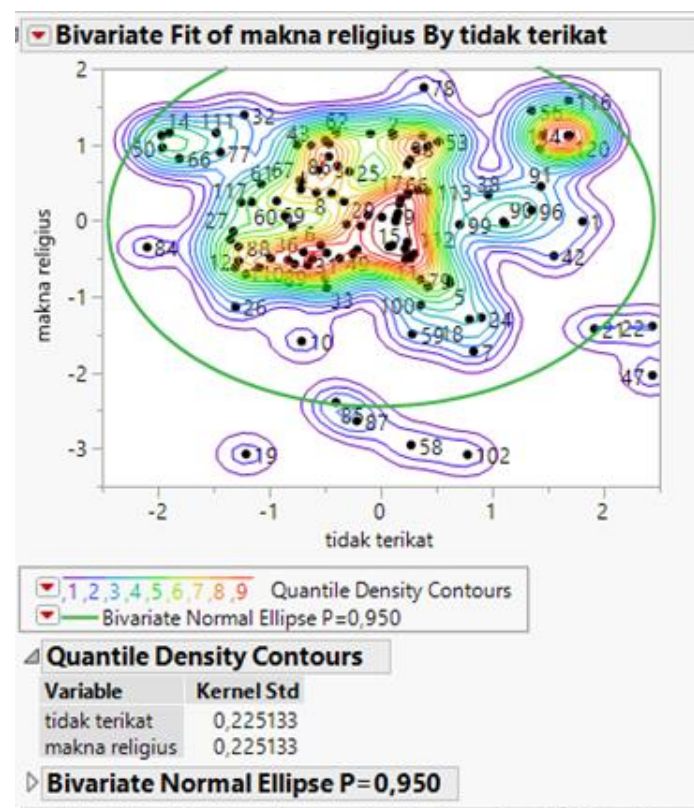

Diagram 11. Density Contour antara Makna Religious dengan Rasa Tidak Terikat
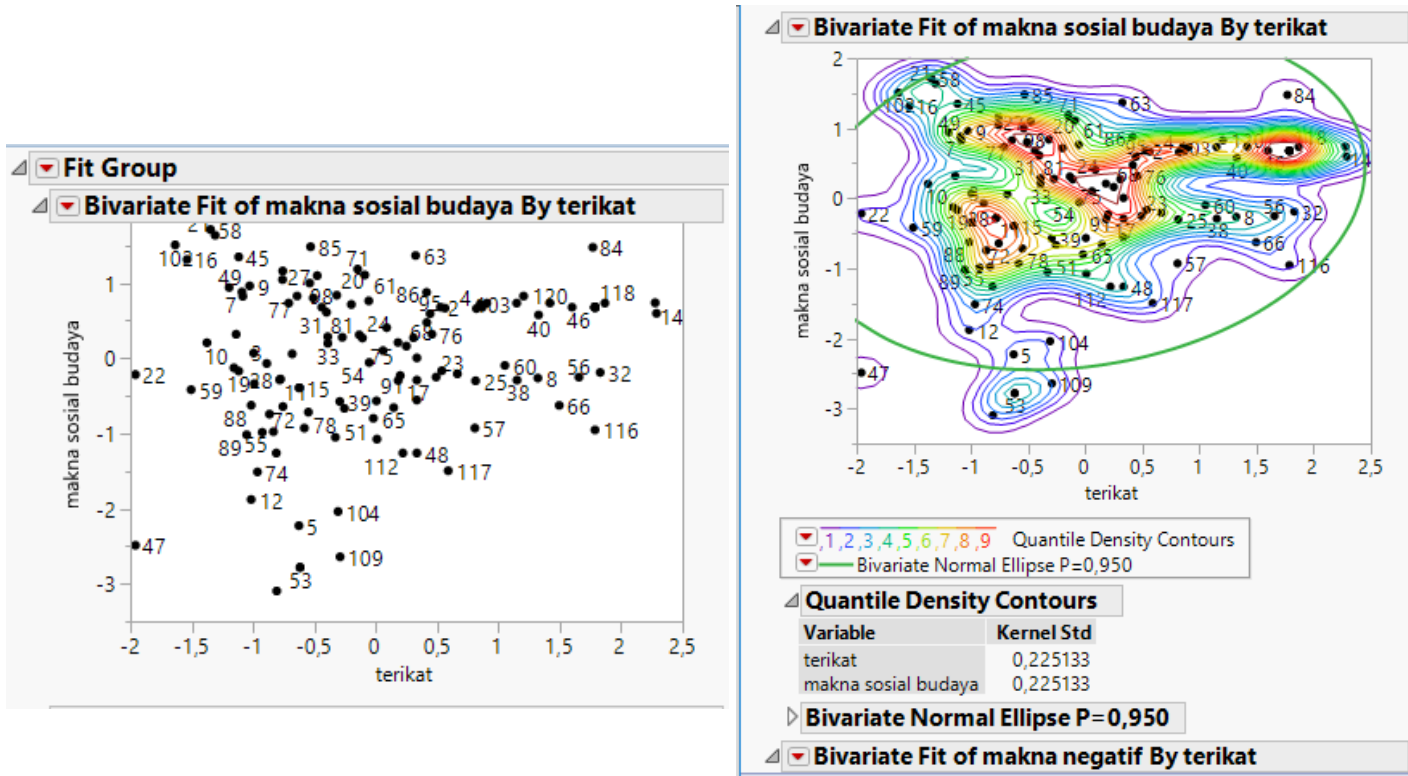

Diagram 12. Density Contours antara Makna Sosial Budaya dan Terikat
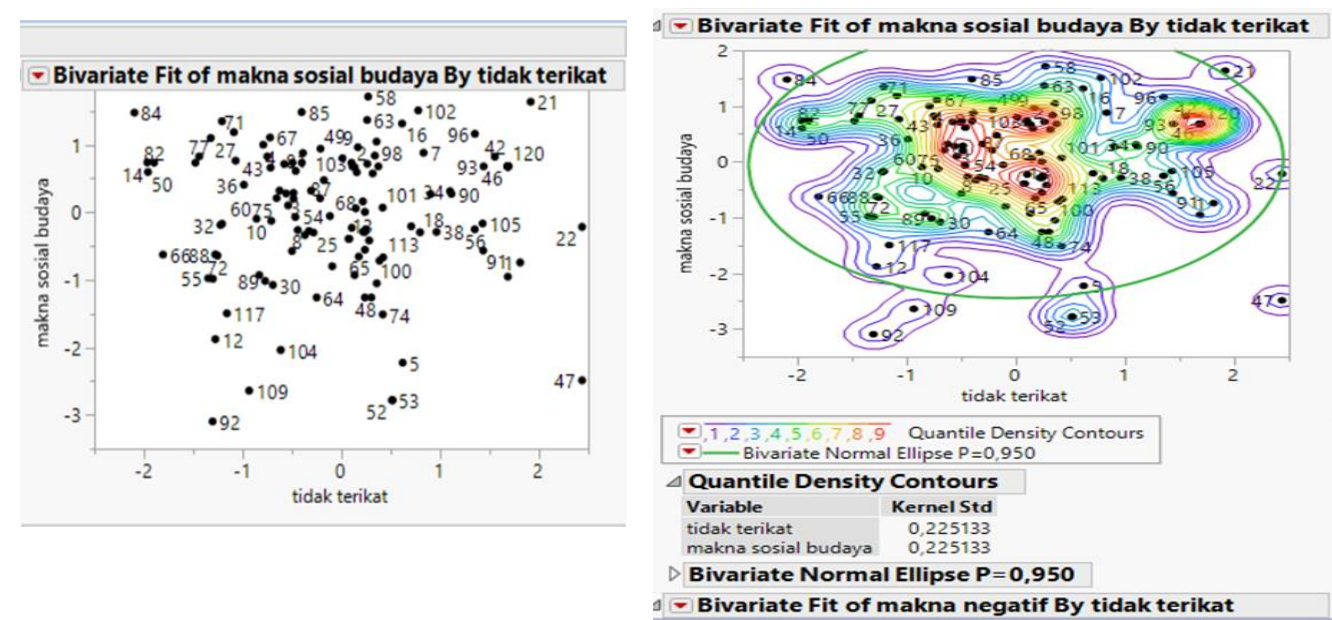

Diagram 13. Tingkat Kepadatan antara Makna Negatif dengan Sense of Place 

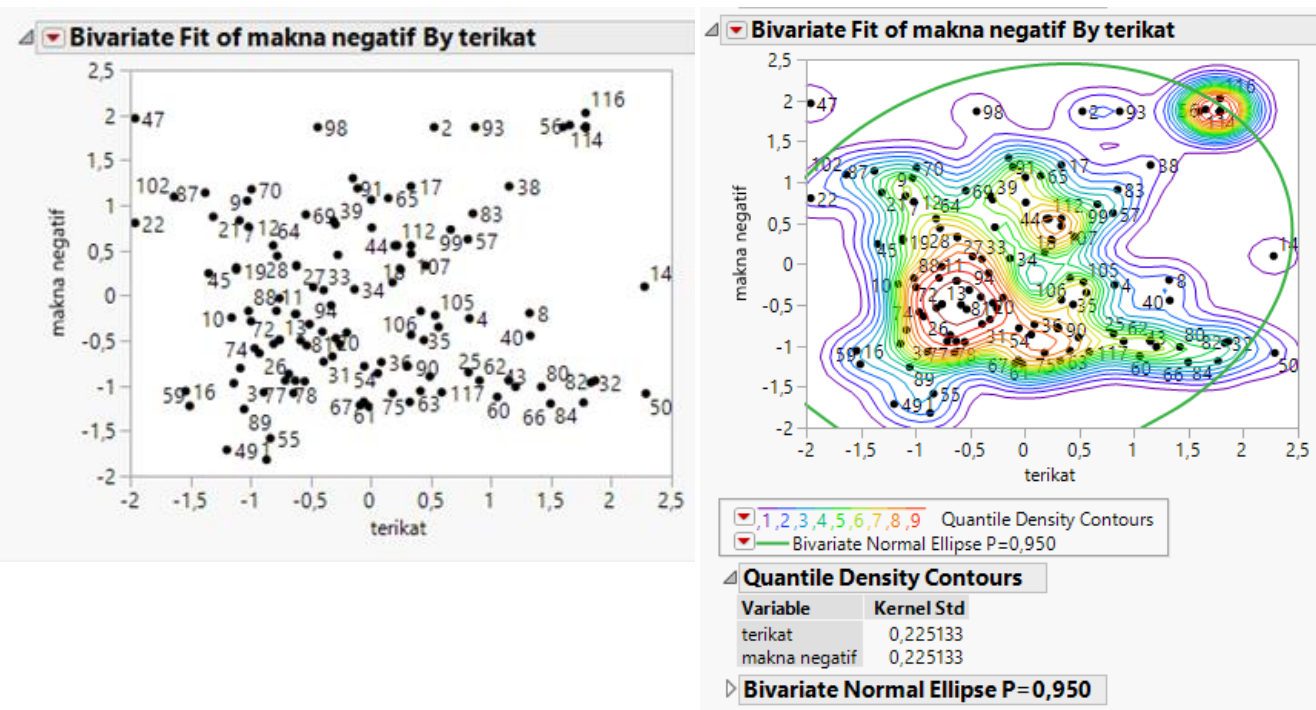

Diagram 14. Density Contour antara Makna Negatif dan Terikat
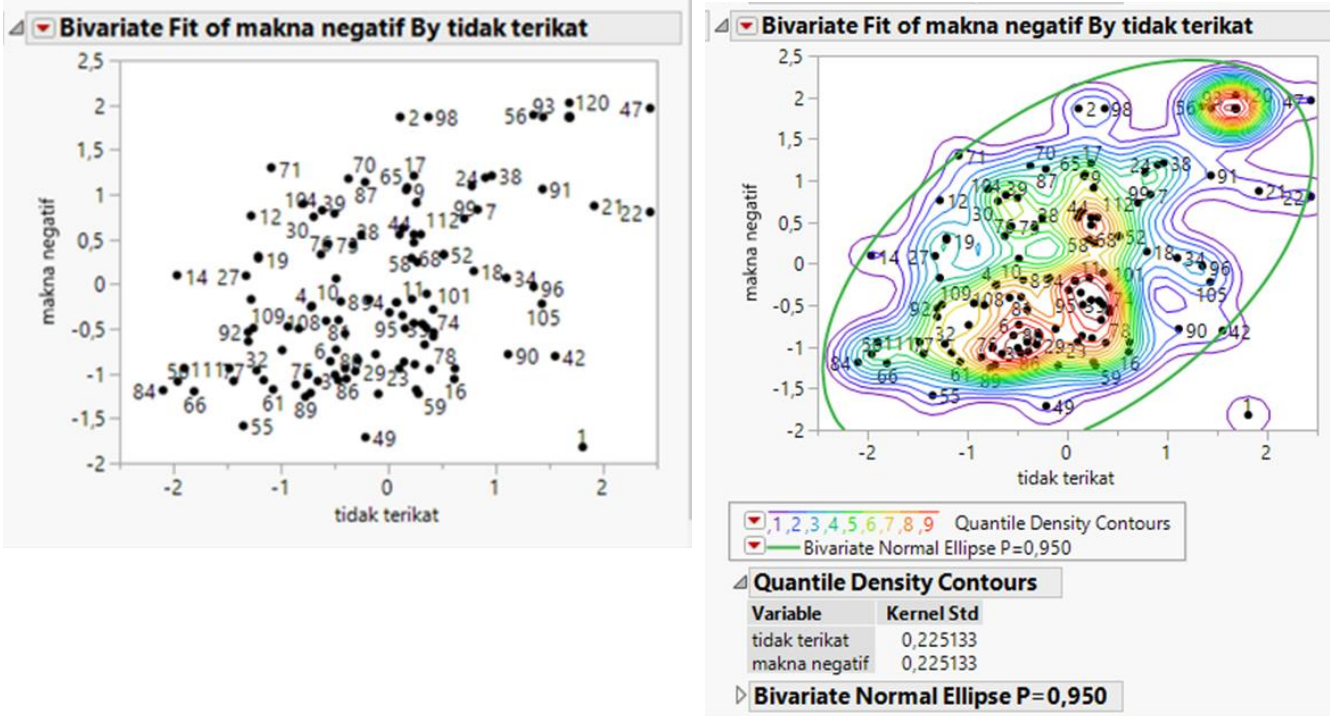

Diagram 15. Density Contour antara Makna Negatif dan Tidak Terikat

\section{PENUTUP}

Pada tahap pertama dilakukan penelitian kualitatif melalui tahap analisis konten. Berdasarkan hasil penyebaran kuesioner diperoleh beberapa kategori makna ziarah yakni ketauladanan, makna budaya, makna sejarah dan edukasi, makna religi, makna social dan tidak bermakna. Berdasarkan analisis distribusi, diperoleh $76 \%$ alasan responden untuk pergi berziarah karena memiliki makna religi yang tinggi.

Pada penelitian ini merupakan kelanjutan dari penelitian tahap pertama, dimana penelitian merupakan penelitian kuantitatif dengan tujuan mengetahui korelasi antara makna ziarah dengan sense of place. Berdasarkan hasil analisis factor, pada makna ziarah dikelompokkan menjadi 3 kategori yakni makna religious, makna sosial budaya dan makna negatif. Sedangkan hasil analisis faktor sense of place, dikelompokkan menjadi terikat dan tidak terikat. Berdasarkan hasil analisis korelasi, terdapat hubungan yang tinggi antara makna religious dengan rasa terikat pada sense of place. Sebaliknya makna negative memiliki korelasi yang tinggi pula dengan rasa tidak terikat. 


\section{UCAPAN TERIMA KASIH}

Penelitian ini terlaksana atas dukungan teman-teman, keluarga dan rekan sejawat, untuk itu penulis mengucapkan banyak terima kasih kepada semua pihak yang telah mendukung terlaksananya penelitian ini. Penulis mengucapkan terima kasih kepada Bapak Dr.Eng.Hanson E.Kusuma, ST, M.Eng selaku dosen mata kuliah Analisi Kualitatif. Terima kasih juga penulis ucapkan kepada teman-teman kuliah di program doktoral arsitektur ITB yang telah membantu dalam proses penyelesaian penelitian ini.

\section{DAFTAR PUSTAKA}

Boerebach, J.J. 2012. Sense of Place, attachment to, identity to, identity with and dependence of shopping location. Eindhoven University of Technology, Redevco B.V.

Holsti, O.R.(1968). Content Analysis, in: Lindzeyg, \& Aronsone. The handbook of social Psychology, vol 2.

Humaidi.2017. Makam Keramat di Jakarta: Jejak perlawanan Melawan Kolonialisme dari masa silam(16401789). Jakarta: Proseding Konferensi Ilmu-Ilmu Sosial.

Junianto, A; Tutut Subadyo. 2016. Konsep Pelestarian Situs Patirtan di Malang Raya sebagai Destinasi Wisata Spiritual. Malang: Proseding Temu IImiah IPLBI

Kusuma, Hanson.E(2015). Memilih Metode Analisis Kuantitatif untuk Penelitian Arsitektur. Bandung: ITB.

Loir, Henri Chambert dan Claude Guillot.2010. Ziarah \& Wali di Dunia Islam. Edisi Indonesia. Jakarta: Kounitas Bambu.

Surya, Syndi Octakomala Dewi. 2016. Korelasi antara aktivitas di taman dengan fungsi taman serta elemen pendukungnya. Malang: Proseding temu Ilmiah IPLBI.

Wasita. 2018. Pemanfaatan Perilaku dan Situasi dalam Prosesi Ziarah pada Tinggalan Arkeologi Sebagai Upaya Pelestarian. Jurnal Kindai Etam, Vol 4(1):73-96

Wawansyah, dkk. 2017. Tradisi ziarah kubur masyarakat Sasak (studi kasus Makam Loang Balo. 